\title{
Autoradiographic Observation of Al-, Mn-, and Na-Distributions on Rock Slice Using Neutron-Induced Radionuclides and Preferential Utilization of Imaging Plate as Its Alternative Detector
}

\author{
Tetsuo Hashimoto, Shuei SAKaue and Hiroto OHIRA* \\ Department of Chemistry, Faculty of Science and \\ *Environmental Science Course, Graduate School of Science and \\ Technology, Niigata University \\ Ikarashi-ninocho, Niigata-shi 950-21, Japan
}

Received August 5, 1992

\begin{abstract}
Autoradiographic observations using a photographic film on a granite rock slice have been established for two-dimensional distribution of elements, $\mathrm{Al}, \mathrm{Mn}$, and $\mathrm{Na}$, which produce relatively short-lived radionuclides after pure thermal neutron irradiation. In the case of aluminium detection, it was suggested from semi-empirical estimation that an obstacle reaction of ${ }^{28} \mathrm{Si}(n, p){ }^{28} \mathrm{Al}$ with fast neutrons significantly overcomes the objective ${ }^{28} \mathrm{Al}$-activity from the neutron capture reaction of aluminium, in addition to the contribution of after-glow phenomena with reactor exposure to sensitize the photographic film. As a result, the fine textures of aluminium pattern among mineral constituents could be conveniently recognized as well as in the case of manganese distribution.

Subsequently, the imaging plate based on photo-stimulated luminescence phenomena has proven to be preferentially employed for the quantitative treatments of imaging patterns due to neutron-induced radionuclides. The advantageous points of the imaging plate, involving ultra-high sensitivity and acquisition of quantitative information, are discussed in comparison with the traditional photographic technique.
\end{abstract}

Key Words : autoradiography, neutron activation, image analysis of element distribution, imaging plate, short-lived radionuclides, rock slices

\section{Introduction}

When rock powder samples were subjected to the neutron irradiation in a reactor, a lot of objective radionuclides could be determined by adjusting the irradiation period of neutrons and the cooling time after irradiation as well known in a neutron activation analysis. An autoradiography using an X-ray film has been proved to be a promising technique to give the characteristic two-dimensional distribution or the elemental images of some $\beta$-ray emitting radionuclides in thin slices or on polished slabs of rock, which are exposed with neutrons. This technique has been ini- tially proposed to be called activography by Banno and Sakanoue et al. ${ }^{1), 2}$, who have measured the distributions of aluminium, manganese, sodium, and iron on garnet, granites, and ore minerals. Subsequently, the activographic technique has been applied to the thin sections of Hawaiian xenolith for the autoradiographic studies of $\mathrm{Mn}, \mathrm{Na}, \mathrm{Cr}$, $\mathrm{Sc}$ and $\mathrm{Co}^{3)}$. Potts has applied this technique to the investigation of the rare earth element and platinum-group element minerals on the basis of nuclear data survey4).

Although the autoradiography renders us convenient and qualitative information concerning the two dimensional distribution of 
radioisotopes, the most drawback appears to be a lack of quantitative information on resultant photographic film in addition to poor sensitivity in comparison with recent electronic apparatus including a photo-multiplier, a photodiode-array, CCD, and some kinds of scintillator.

Recently, an imaging plate, which is an innovative two-dimensional sensor of radioactive energy memory type, has been available in a variety of radiographic fields ${ }^{5)}$. The imaging plate (IP) method, not only visualizes the latent $\beta$-radiation image with high sensitivity through the digital process of conventional radiation sensors, but also makes it possible to quantify the location and intensity of the radiation image.

In the present experiments, the activography has been researched from aspects of $\mathrm{Al}, \mathrm{Mn}$ and $\mathrm{Na}$ distribution on a granite slice, which were subjected to pure thermal neutron irradiation. Then technique using the IP has been developed the quantitative analysis of twodimensional characteristic distribution of objective radionuclides in the irradiated granite slice. The IP results were also compared with the ordinary autoradiography.

\section{Experimental}

\subsection{Sample preparation}

The granite samples were collected from Hanawa pluton (Fukushima, Japan), which has been described from the view-points of zircon morphology by Ohira ${ }^{6)}$. Two typical granites rocks, consisting of HW-2 (milonitelike granodiorite) and HW-44 (porphyritic granodiorite), were sliced into about $15 \times 15 \times$ $0.5 \mathrm{~mm}$ plates, of which both sides were polished with alumina emulsion solution. The objective slice samples were selected which contain a variety of minerals as distinctly as possible.
2.2 Neutron irradiation and activography procedure

As described below, for the purpose of irradiation with the purest thermal neutrons, a pneumatic tube transportation system (TCPn) installed in a graphite thermal column of KUR (Kyoto University Reactor), Research Reactor Institute of Kyoto University was used.

The irradiation conditions of TC-Pn at operation power of $5000 \mathrm{~kW}$ are as follows; $\phi_{\mathrm{th}}$ $=4 \times 10^{11}, \phi_{\text {ep } 1}=6 \times 10^{8}, \phi_{\mathrm{f}}=8 \times 10^{7}\left(\mathrm{n} / \mathrm{cm}^{2} \mathrm{~s}\right), \gamma=$ $2 \times 10^{5} \mathrm{R} / \mathrm{h}(1.7 \mathrm{kGy} / \mathrm{h})$, and ambient temperature of about $50{ }^{\circ} \mathrm{C}$. In order to prevent the sample from crushing, the sliced sample was wrapped with a small package of styrene foam and this pack was input into a large polyethylene capsule (rabbit).

The transportation time from the rabbit filling position to the irradiation position requires approximately a few seconds. The irradiation time was always fixed to $1 \mathrm{~min}$ except $5 \mathrm{~min}$ for the traditional autoradiography. The irradiated rock slice was adhered on a small lead disk having $50 \mathrm{~mm}$ in diameter and $10 \mathrm{~mm}$ in thickness to avoid meaningless exposure. This stack was followed to the exposure directly onto an autoradiographic film (Neopan-SS, Fuji Film Co.) in a dark bag or an imaging plate (IP $200 \times 400 \times 0.5 \mathrm{~mm}$ in size, Fujix Bio-Imaging Plate, Fuji Film Co.) packed tightly with a dark polyethylene bag (less than $0.1 \mathrm{~mm}$ in thickness).

The imaging plate is a flexible image sensor in which bunches of extremely small crystals (about $5 \mu \mathrm{m}$ in grain size) of photo-stimulatable phosphor of barium floride bromide containing a trace amount of bivalent europium as a luminescence center, formulated as $\mathrm{BaFBr}: \mathrm{Eu}^{2+}$, are uniformly coated $150-$ to $300-\mu \mathrm{m}$ thick on a polyester support film ${ }^{7}$. The cooling time and the exposure time were adjusted for each objective radionuclides and for either of two detectors, although the imaging plate usually needed shorter exposure 

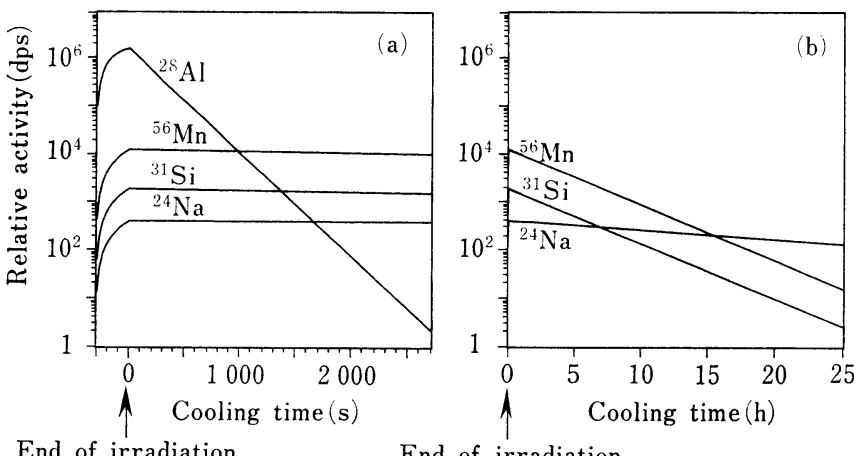

End of irradiation

Fig. 1 Calculated growth and decay curves for main short-lived radioactive nuclides produced by neutron irradiation of quartz sample.

Thermal neutron flux is $4.0 \times 10^{11} \mathrm{n} / \mathrm{cm}^{2} \mathrm{~s}$ at TC-Pn in $\mathrm{KUR}$, and $\mathrm{Al}, \mathrm{Mn}$ and $\mathrm{Na}$ contents are assumed to be $100 \mathrm{ppm}$, and $1 \mathrm{ppm}$ and $10 \mathrm{ppm}$ in quartz, respectively. Abscissa scales of (a) and (b) are expressed in seconds and hours, respectively.

as described later.

The exposed IP was transported under cooling condition at approximately $0{ }^{\circ} \mathrm{C}$ to conserve the labile luminescence centers. The IP in a special magazine was inserted in an image reader (BAS 2000, Fuji). The IP-reader could scan the IP with a fine laser beam (He-Ne laser, $633 \mathrm{~nm}$ ) which can induce luminescence $(400 \mathrm{~nm})$ in proportion to the recorded radiation intensity. This photo-stimulated luminescence intensity was converted into electrical signals after detecting with a photomultiplier tube. The $\beta$-radioactive image recorded on the IP during the exposure was read as high resolution digital data of 10 pixels $/ \mathrm{mm}$ and registered in an analyzing unit (32-bit workstation), in which a variety of image analyses can be processed ${ }^{5), 7)}$.

\section{Results and Discussion}

$3 \cdot 1$ Selection of neutron irradiation facilities

Prior to autoradiographic procedure (socalled activography) associated with neutron activation analysis, some evaluation of induced activity strength was carried out. In the neutron activation analysis, an intensity due to a certain radioactive nuclide amongst many induced activities is apparently dependent on the irradiation time $\left(t_{1}\right)$ and the cooling time $\left(t_{\mathrm{c}}\right)$ after the irradiation as well as the reaction cross sections $(\sigma)$. When the contents of $\mathrm{Al}, \mathrm{Mn}$, and $\mathrm{Na}$ in a quartz material are assumed to be 100,1 , and $10 \mathrm{ppm}$, respectively and the irradiation is conducted for $5 \mathrm{~min}$ in the TC-Pn facilities, the changes of the calculated radioactivity regarding induced short-lived radionuclides are illustrated in Fig. 1. From this figure, it is evident that ${ }^{28} \mathrm{Al}$ $\left(T_{1 / 2}=2.24 \mathrm{~min}\right.$ ) occupies predominant activity within $10 \mathrm{~min}$ after irradiation while ${ }^{56} \mathrm{Mn}(2.579 \mathrm{~h})$ and ${ }^{24} \mathrm{Na}(15.02 \mathrm{~h})$ constitute in turn as stronger activities than any concomitant ones with longer cooling time. Fortunately, because of poor abundance (3.12 $\%$ ) of ${ }^{30} \mathrm{Si}$ and a small neutron capture cross section $(110 \mathrm{mb}),{ }^{31} \mathrm{Si}(2.62 \mathrm{~h})$ will not disturb even among short lived nuclides although silicate minerals are usually comprised of the matrix element, Si. Activity changes of these short-lived nuclides were experimentally ascertained with $\gamma$-ray spectrometry after the neutron irradiation. As shown in Fig. 2, the activity due to ${ }^{28} \mathrm{Al}$ actually precedes within $10 \mathrm{~min}$ after the irradiation and then ${ }^{56} \mathrm{Mn}$ and ${ }^{24} \mathrm{Na}$ successively yield dominant activity as predicted in Fig. 1. On the basis of these results, the exposure times for the concerned nuclides after the irradiation are considered.

In the case of aluminium analysis in silicates, an additional attention has been paid to the inevitable formation of the same radioactive nuclide, ${ }^{28} \mathrm{Al}$, through an obstacle simultaneous reaction of ${ }^{28} \mathrm{Si}(\mathrm{n}, \mathrm{p}){ }^{28} \mathrm{Al}$ with fast neutrons. Since the target nuclide, ${ }^{28} \mathrm{Si}$, is the most abundant existence amounted to $92.18 \%$ in addition to silicon regarded as a 


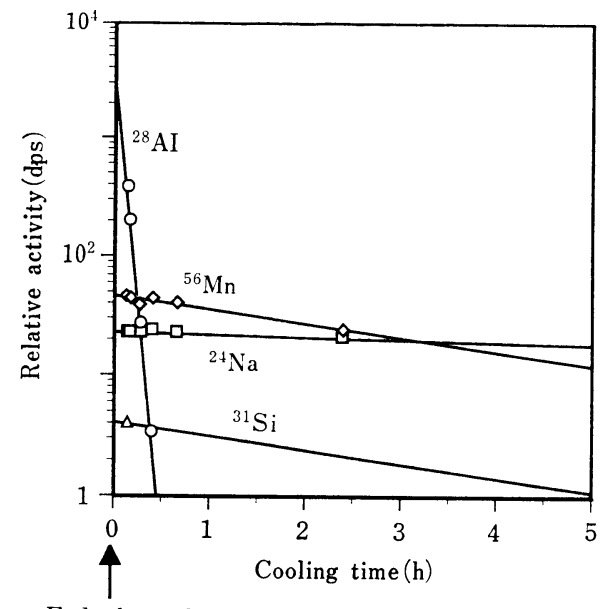

End of irradiation

Fig. 2 Some decay curves of ${ }^{24} \mathrm{Na},{ }^{28} \mathrm{Al},{ }^{31} \mathrm{Si}$ and ${ }^{56} \mathrm{Mn}$ produced by neutron irradiation to the granite slice, $\mathrm{HW}-2$.

Thermal neutron flux is $4.0 \times 10^{11} \mathrm{n} / \mathrm{cm}^{2} \mathrm{~s}$ at TC-Pn in KUR, and irradiation time is $1 \mathrm{~min}$. Abscissa scales is expressed in hours.

most plentiful element in silicate, the contribution of this nuclear reaction should be considered if the irradiation site includes some fast neutrons. From this standpoint, the formation ratio $(R)$ of ${ }^{28} \mathrm{Al}$ by the $(\mathrm{n}, \mathrm{p})$ reaction of ${ }^{28} \mathrm{Si}$ against by the neutron capture reaction of ${ }^{27} \mathrm{Al}$ was calculated using $(\mathrm{n}, \mathrm{p})$ reaction cross section $\left(\sigma_{\mathrm{f}}\right)$ of $6.4 \mathrm{mb}^{9)}$ with fast neutrons as follows;

$$
R=\left(\sigma_{\mathrm{f}} \phi_{\mathrm{f}} / \sigma_{\mathrm{th}} \phi_{\mathrm{th}}\right)\left(N^{28 \mathrm{Si}} / N^{27} \mathrm{Al}\right)
$$

where ${ }^{28} \mathrm{Si}$ and ${ }^{27} \mathrm{Al}$ are numbers of ${ }^{28} \mathrm{Si}$ and ${ }^{27} \mathrm{Al}$ isotopes in silicate samples. For the sake of the comparison of the detection criterion for available irradiation facilities, $\mathrm{Pn}-3$ as a general irradiation facility having a $C_{\mathrm{d}}$-ratio of $6.2, \phi_{\mathrm{th}}=2.3 \times 10^{13}$ and $\phi_{\mathrm{f}}=4.8 \times 10^{12}\left(\mathrm{n} / \mathrm{cm}^{2}\right.$ s) and, TC-Pn as a pure thermal neutron facility of KUR, the following equations can be introduced by adopting known values,

$$
\begin{aligned}
& \text { for } \mathrm{Pn}-3 \quad R=6.77 \times 10^{3} / \mathrm{Al}(\mathrm{ppm}) \\
& \text { and for TC-pn } \\
& \qquad R=6.61 / \mathrm{Al}(\mathrm{ppm})
\end{aligned}
$$

where $\mathrm{Al}$ (ppm) is aluminium concentration of silicate minerals in ppm unit. From these equations, it is easily understandable that the determination of aluminium in a few hundred ppm levels as seen in general silicates will become impossible if the Pn-3 irradiation facilities were used; in such case the interfering reaction through $(n, p)$ for the formation of ${ }^{28} \mathrm{Al}$ will overcome the neutron capture reaction up to several tens times. Therefore, the activation analysis of aluminium could be recommended to be performed in the thermal neutron facilities as pure as possible, such as in the TC-Pn. Practically, a synthetic quartz glass of extra pure grade made from pure $\mathrm{SiF}_{4}$ gas was irradiated in both Pn-3 and TC-Pn of KUR and the analyzed Al contents were evaluated to be 2034 and $1.93 \mathrm{ppm}$, respectively, although this quartz glass sample is certified to contain no aluminium. From this result, it was also recognized that the concomitant fast neutrons in the Pn-3 significantly brings on the ${ }^{28} \mathrm{Al}$-formation through the $(n, p)$ reaction rather than the $(n, \gamma)$ one. The ratio of final detection limits for aluminium was estimated to be 1053 times, being in good agreement with calculated value of 1026; this means that the TC-Pn irradiation is superior to the Pn-3 in sensitivity of aluminium detection. Therefore, the neutron irradiation was appropriately carried out in the TC-Pn facilities throughout the present experiments.

3.2 Imaging of neutron-induced nuclides

Two typical traditional autoradiographs together with a photo of the granite surface using an ordinary photographic film are shown in Fig. 3 (a), (b), (c), which correspond to a real granite slice surface, Al-, and $\mathrm{Mn}$ patterns, respectively, by controlling the exposure time with the film surface as well as the cooling time. The similar activographs for a granite specimen have been reported by Sakanoue et al. ${ }^{1,2)}$. However, in their activographic method, they didn't pay any attention to the influence of fast neutrons as mentioned 

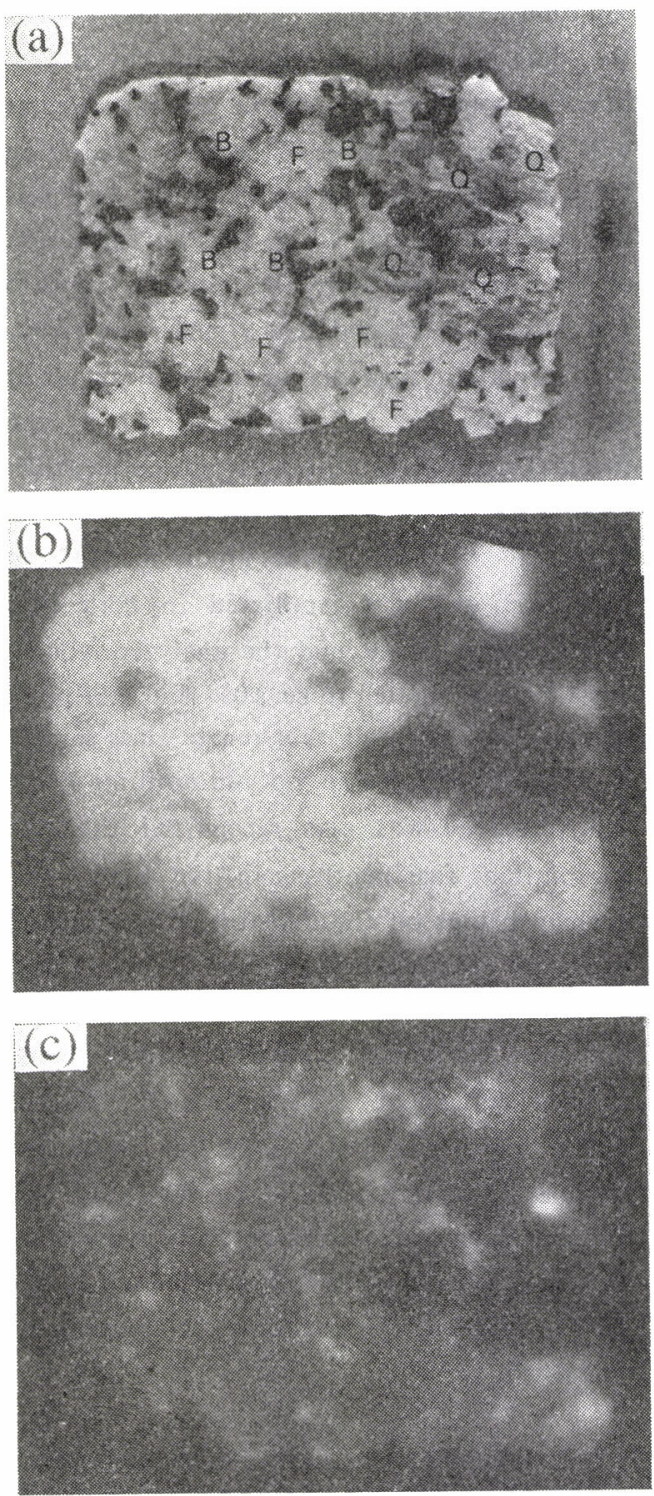

$10 \mathrm{~mm}$

Fig. 3 Traditional autoradiographs derived from neutron-induced ${ }^{28} \mathrm{Al}$ - (b) and ${ }^{56} \mathrm{Mn}$-distribution (c) on granite slice surface (a). The granite sample, HW-44, is employed (Q: quarts, F: feldspar, B: biotite). The irradiation time, cooling time and exposure time were $1 \mathrm{~min}, 2 \mathrm{~min}$ and 3 min for photo (b), and $1 \mathrm{~min}, 32 \mathrm{~min}$ and $54 \mathrm{~min}$ for photo (c), respectively. above.

In addition to this contribution, the afterglow phenomena of the exposed slice rocks, which have been initially color-photographed by the authors ${ }^{8)}$, have to be taken into account of the photographic images immediately after the exposure on the basis of the dose rate changes. It was found that the after-glow color images (AGCI) had to be recognized even for several minutes irradiation at a position of $0.32 \mathrm{kGy} / \mathrm{h}$ of a ${ }^{60} \mathrm{Co}$-source. In practice, the Pn-3 irradiation site, which had been used also by Sakanoue et al. ${ }^{1,2)}$, possesses remarkably high dose rate such as $6.1 \times$ $10^{2} \mathrm{kGy} / \mathrm{h}$ due to concomitant reactor $\gamma$-rays, so that the after-glow intensity of rock slices even for 5 min irradiation should be extremely strong even $30 \mathrm{~min}$ after the irradiation ${ }^{81}$. This after-glow emission must certainly cause any sensitizing effects on the photographic film which was directly contacted with the reactor-irradiated sample. Therefore, the aluminium activographs by the preceding paper ${ }^{22}$ must be pseudo images due to an after-glow overlapped with silicon matrix containing ${ }^{28} \mathrm{Si}$ itself instead of the aimed aluminium distribution; this Al-activograph is presumably attributed to matrix silicates. On the other hand, the present distribution pattern of aluminium as shown in Fig. 3(b) is convinced to reflect actually the aluminium position on granite surface, because the irradiation conditions (TC-Pn), pervading thermal neutrons as pure as possible and lower $\gamma$-rays exposure rate were employed on the basis of critical examination as described above. In fact, subtle and weak textures due to biotites were apparently recognized togther with homogeneously distributed aluminium images due to feldspars as well as negligible existence of aluminium corresponding to quartz portions. The almost similar Al-distribution has been also ascertained from an electron microprobe analysis (EPMA). Such effect due to the afterglow effects should be sometimes noticed even 
for the manganese activography owing to the long-lived fluorescence even several tenths minutes after the irradiation. As reported in the previous papers $\left.{ }^{8)}, 10\right), 11$, it has been found that the contents of aluminium impurity in white mineral constituents are greatly correlated to some luminescence properties involving emission spectrum and intensity. Therefore, further discussion from this approach will be given elsewhere ${ }^{12)}$. In spite of these improvement of the activography, there remains inevitable problems associated with non-linear feature of the traditional autoradiography.

\subsection{Preferential utilization of imaging plate}

Concerning the quantitative distribution of radioactive nuclides, the use of imaging plate (IP) has been attempted instead of the traditional autoradiograph with a photographic or $\mathrm{X}$-ray film. Figure 4 (a) and (b) show manganese and sodium distributions on the same granite slice photographed from a display of the IP reader. The manganese distribution pattern is almost analogous to the Fig. 3 (c), although the applied exposure time of IP was less than one tenth of the traditional autoradiograph. In the case of sodium, the dense distribution patterns prominently appear on the position corresponding to the colored minerals like biotite as well as in the case of manganese. Moreover, as mentioned above, the data are registered on each file as digital values, which could be followed to a variety of computer processing. This means that the versatile applications based upon quantitative analysis of the acquired data become possible; practically, the linear relationship between concentration of $\beta$-ray source $\left({ }^{14} \mathrm{C}\right)$ and the detection intensity as emitting photon-intensity has been verified to hold in a wide range of $10^{-1}$ to $10^{5} \mathrm{dpm} / \mathrm{mm}^{2}{ }^{7)}$. Similarly, the detection intensity (sum of digital values from pixels) of photo-stimulated luminescence from the IP reader on some pieces of rock slices was plotted against their sodium contents which were determined by a separate instrumental neutron activation analysis (INAA). The result are summarized in Fig. 5, together with those from the EPMA. In this figure, one can readily recognize the presence of apparent linearity between detected intensity and $\mathrm{Na}$ concentrations as expected, so that the quantitative information regarding each element distribution will be obtained from the use of the IP. In fact, the sodium distribution pattern along an A-B line is indicated in Fig. 4(c) by normalizing known sodium concentrations from a few of portions which were determined by neutron activation analysis. The results from sodium usually showed monotonous distribution on the feldspar $\mathrm{mi}-$ nerals. The similarly analyzed curve for manganese data showed the apparently saturated density of IP at higher value of extracted pixeles owing to the excess of exposure period. Moreover, the aluminium pattern on the IP for $30 \mathrm{~s}$ exposure at $5 \mathrm{~min}$ after irradiation gave completely saturated values all over surface area although the traditional autoradiograph couldn't bring about any useful images on the same conditions. From these facts, it was confirmed that the IP sensitivity is extraordinarily high in comparison with an ordinary photographic film. Moreover, it is very useful for the quantitative image analyses after saving the registered data into a magnetic tape or a floppy disk. The utilization of the IP is furthermore preferable for the element mapping due to longer-lived radionuclides, which are desirable to be produced as low as possible in a reactor irradiation from the viewpoints of sample storage and waste disposal. The nuclear data evaluations for the mapping of trace elements including rare earth elements, REE, have been carried out by Potts ${ }^{4}$.

The features of the imaging plate (IP) become apparent when compared with the or- 

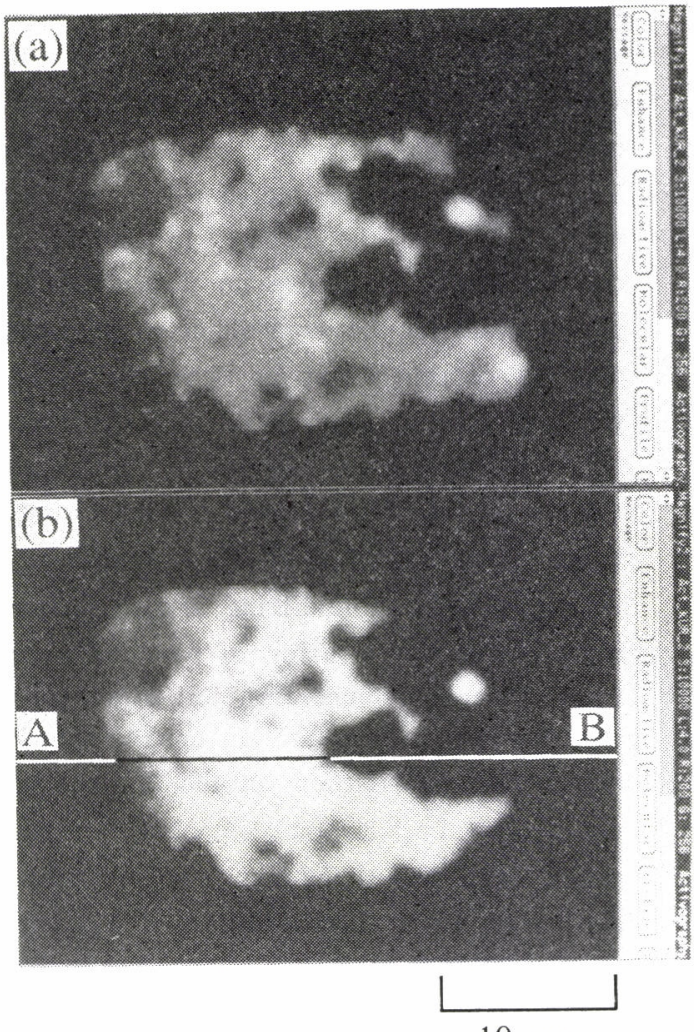

$10 \mathrm{~mm}$

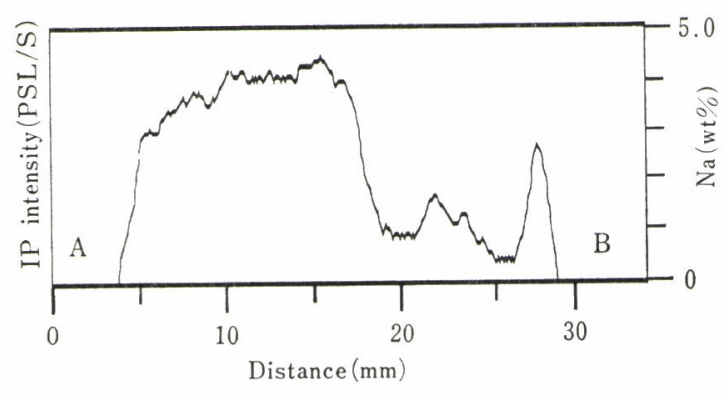

Fig. 4 Typical two-dimensional patterns of Mn (a) and $\mathrm{Na}(\mathrm{b})$ in granite slice, and $\mathrm{Na}$ distribution pattern (c) along $\mathrm{A}-\mathrm{B}$ line using imaging plate (IP).

The granite slice sample is HW-44. The irradiation time, cooling time and exposure time were $1 \mathrm{~min}, 2.5 \mathrm{~h}$ and $5 \mathrm{~min}$ for photo (a) and $1 \mathrm{~min}, 5 \mathrm{~h}$ and $10 \mathrm{~min}$ for photo (b), respectively. Photographs were taken from IP reader display (BAS 2000). Ordinate in (c) shows intensity of photo-stimulated luminescence and $\mathrm{Na}$ contents along $\mathrm{A}-\mathrm{B}$ line.

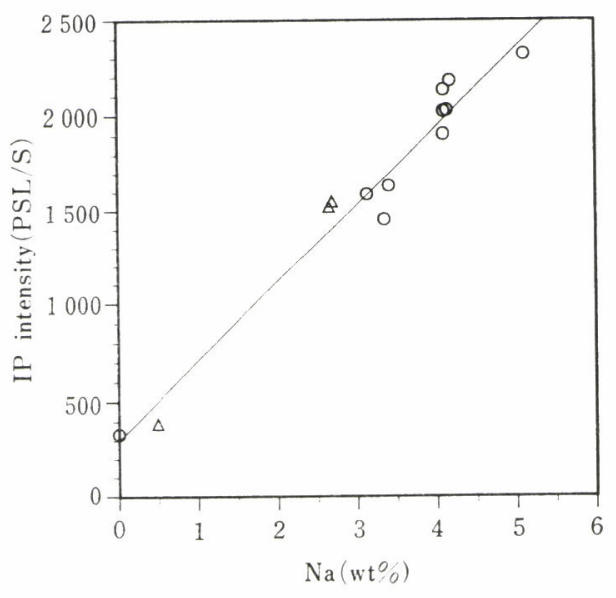

Fig. 5 Relationship between the $\mathrm{Na}$ concentrations and the intensity of photo-stimulated luminescence from IP.

The exposure of the IP was adjusted to record only ${ }^{24} \mathrm{Na}$-activity after decaying out all of ${ }^{56} \mathrm{Mn}$ at cooling time of about $5 \mathrm{~h}$. Na concentrations were determined by INAA $(\triangle)$ and EPMA $(\bigcirc)$.

dinary autoradiography using photographic films as follows: (1) the IP possesses ultrahigh sensitivity up to several ten times more sensitive than photographic film; the IP can be dealt even under weak lightning. (2) The IP gives wider dynamic range with superior linearity, being a wider range of $10^{4}$ to $10^{5}$, as seen partly in Fig. 5, whereas the photographic method possesses a narrow one of $10^{2}$ order. (3) Since digital electronic signals for corresponding higher pixel density are directly available from the reader, computer processing or combination with other electronic systems can be applied as known for a variety of image analyses. (4) Owing to an integral-type detector, the IP method with short exposure produces less detection counting errors even at a high flux density which is of ten encountered in some pulse-type detectors. (5) The accumulated background can be completely erased before repeated use; the use of the IP should be avoided under the exposure of intense lightning like the sun light owing to the fading effects. (6) Since 
the IP possesses the nature of flexibility in any directions for handling, it can be applied to any specimens prevailing somewhat rough surface.

Anyhow, the highly sensitive activography using the IP detector combined with neutron activation has proven to be useful for the quantitative analysis of two-dimensional distribution of trace impurities in many kinds of solid surfaces. This method will make great contribution not only for a petrology or a geology, but also in many scientific fields including a solid, surface, and catalyst chemistry, a semiconductor physico-chemistry, a biological science and so on.

\section{Acknowledgements}

The authors are extremely grateful to Dr. R. Kuwano of the Research Laboratory for Molecular Genetic, Niigata University, for providing many useful information and permission to use imaging plate reader; to $\mathrm{Mr}$. M. Kobayashi of School of Dentistry, Niigata University, for assistance of the electron $\mathrm{mi}$ croprobe analyzer.

This work has been performed in part by using facilities of the Research Reactor Institute, Kyoto University and the authors would like to express their appreciations to Dr. K. Kobayashi, Messrs. R. Matsushita and T. Warashina for their valuable suggestion and kind help of neutron irradiation.

The present work was supported in part by a Grant-in-Aid for Fundamental Scientific Research from the Ministry of Education and Culture, Japan (No. 03554023).

\section{References}

1) Banno, S., Sakanoue, M. and Nakanishi, T.: Geochem. J., 4, 75-81 (1970)

2) Sakanoue, M., Yoshioka, M., Nakanishi, T. and Takagi, T.: J. Appl. Radiat. Isot., 22, 177-183 (1971)

3) Beeson, M.H. and Beeson, M.H.: Am. J. Sci., 280-A, 450-470 (1980)

4) Potts, P.J.: Economic Geology, 79, 738-747 (1984)

5) Amemiya, Y. and Miyahara, J.: Nature, 336, 89-90 (1988)

6) Ohira, H.: J. Miner. Econom. Geol., 87, 86-101 (1992)

7) Miyahara, J.: Chemistry Today, 223, 2936 (1989)

8) Hashimoto, T., Sakaue, S., Kojima M. and Sakai, T.: Radioisotopes, 40, 219-225 (1991)

9) IAEA: "Handbook on Nuclear Activation Cross-Sections", IAEA Technical Reports, No. 156 (1974)

10) Hashimoto, T., Sakai, T., Takahashi, S. and Habuki, H.: Proceedings of International Symposium on Advanced Nuclear Energy Reseach-Near-future Chemistry in Nuclear Energy Fields, P-IV-15, 478482 (1989)

11) Hashimoto, T., Sakai, T., Shirai, N., Sakaue, S. and Kojima, M.: Anal. Sci., 7, 687-690 (1991)

12) Hashimoto, T., Yokosaka, K., Notoya, S., Ojima, T. and Sakaue, S.: Nucl. Track Radiat. Measur., to be accepted 
旨

\title{
中性子放射化 RI を用いた岩石薄片中の $\mathrm{Al}, \mathrm{Mn}, \mathrm{Na}$ のオートラジオ グラフ観察と新たな検出材としてのイメージングプレートの有用性
}

\author{
橋本哲夫, 坂上修栄, 大平寛人* \\ 新潟大学理学部化学科, *同大学大学院自然科学研究科 \\ 950-21 新潟市五十嵐 2 の町 8050
}

\begin{abstract}
花崗岩中には，純粋な熱中性子を照射したさいに比較的短い半隇期の放射性核種を生成する， $\mathrm{Al}, \mathrm{Mn}, \mathrm{Na}$ などの不純物元素が含まれている。花崗岩薄片試料中の中のこれら $\mathrm{Al}, \mathrm{Mn}, \mathrm{Na}$ など の不純物元素の二次元的な分布を観察するために, 中性子照射後の泠却時間变化と写真フィルムを 用いたオートラジオグラフ観察を行った。しかしながら，従来法で $\mathrm{Al}$ の分布パターンを検出する さいには, ${ }^{27} \mathrm{Al}$ の中性子捕獲反応によって生成する目的核種, ${ }^{28} \mathrm{Al}$ の放射能以外飞, 混在する速中 性子による妨害反応 ${ }^{28} \mathrm{Si}(\mathrm{n}, \mathrm{p}){ }^{28} \mathrm{Al}$ に基づく ${ }^{28} \mathrm{Al}$ 生成の寄与が大きく，また $\gamma$ 線線量率の高い原 子炉照射に伴い，花崗岩薄片試料から写真フィルムに対して感度の高いアフターグローが発生する ために，得られたパターンが必ずしも純粋に元素としての $\mathrm{Al}$ の分布を反映していないという欠点 があった。そこで，今回の実験では，この 2 点を考慮し，純粋な熱中性子が得られ， $\gamma$ 線線量率の 比較的低い，熱中性子照射設備（京都大学原子炉黒鉛設備圧気輸送管）を用いた。その結果，アル ミニウムの微細な分布パターンやマンガンの釷物間分布を簡便に得ることが可能となった。

また同様の実験を, 写真フィルムに代えて，イメーシシングプレートを用いて行ったところ, 非常 に高感度であり，多面的に利用できる定量的情報を得ることが可能であることが確認できた。中性 子放射化オートラジオグラフ法に拈いてイメージングプレートを利用するさいの利点に関して, 従 来の写真観察法と比較して議論した。
\end{abstract}

